Irwanda Wisnu Wardhana - Dhani Setyawan - Khairunnisah

\title{
DETERMINANTS OF LABOR MARKET IN JAKARTA METROPOLITAN AREA: A SURVIVAL ANALYSIS OF COMMUTERS
}

This study aims to assess the determinants of the labor market in the Greater Jakarta Area (Jabodetabek) with a population of 27.9 million (2010 census) and growth rate of 3.6 percent per annum over the period 2000-2010. With a total area of 4,384 square kilometers (1,693 sq mi), the city has a very high population density of 14,464 people per square kilometer (37,460/ sq mi), while the metro area has a density of 4,383 people/sq km (11,353/sq mi). The paper employs the survival regression analysis by incorporating attributes of commuter, namely gender, age, distance, travel time, wages, stress, education level, double income households and home ownership. The area consists of Jakarta as the receiving labor market and eight municipalities and regencies as labor suppliers. The study utilizes a cross-section data from a commuter survey with more than 4,000 respondents participated using different modes of land transport. The results reveal that some determinants have influenced commuters' resiliency and their willingness to participate in the receiving labor market. This study found that gender, distance, wages and home ownership do not affect the respondent's decision whether to stay or quit as commuters. On the other hand, the fittest model exhibits that age, education level, stress, travel time and double income households have significant effects on individual's decision to stay or quit as a commuter. It is found that gender, distance, wages and home ownership do not matter for respondent's decision on whether to stay or to quit as commuters. The model exhibits that age, education level, stress, travel time and double-income household have significant effects on an individual's decision to stay or quit as a commuter. Education level has a positive effect; on the other hand, age, stress, double-income household and travel time have a negative effect. The policy implications for improving the labor supply provision and some contested policy options are suggested, such as the provision of affordable housing in Jakarta, the improvement of commuting enjoyment, the establishment of child care facilities in the office buildings and the creation of more sophisticated jobs within the Jakarta's surrounding municipalities and regencies.

Keywords: commuter, labor supply, survival analysis, transportation

\section{Introduction}

Jakarta, as Indonesia's capital city, has been a magnet to every immigrant to work. Aside from being the center of every governance activity, Jakarta economic activities also attract more labors, especially from the outside of Jakarta. Although Jakarta's economic growth tend to fluctuate, from $5.97 \%$ to $5.93 \%$ in the first quarter of 2018 , Jakarta has contributed 17\% to Indonesia's economy [1]. Higher pay and more abundant opportunities are some factors influencing individual decision to move to Jakarta. Some of them are willing to travel for 10 or more hours in order to relocate to Jakarta.

Not only attracting those who lived 10 hours away from Jakarta, labor from districts and cities that circled Jakarta also attracted to gamble in this city, to have a better life through higher pay and a more suitable job that match their qualifications. Those who live in the outskirt of Jakarta are willing to travel back and forth from their home to their workplace in Jakarta. These people are known as commuter labors. There are 2.43 million commuters who are traveling within, into and out of the city in a day. Of these people, 1.38 million are those who live in the outskirt of Jakarta, such as Depok, Tangerang, Bogor, Bekasi, and Banten [2].

This study would like to assess the determinants of commuter labor on their decision making to be a commuter and fulfill Jakarta's market labor. By employing a survival regression analysis, this study will shed light on how commuter labors decide to stay or quit as a commuter in the future.

\section{Literature review}

In the last two decades is recorded a very high growth of population in developing countries [3]. In line with the growing population, the needs of mobility are also increasing. Accessibility of a sound public transport system has become more important in order to design and to evaluate sustainability of a transit system. Besides the transport system, access for public transport has been 
considered to have an impact to life satisfaction [4-5]. If the high demands of public transports were not able to meet a certain level of supply of transport infrastructure that may lead to congestions and increasing of waiting times in the streets and public transport hubs [6]. Improvements in the public transport systems lead to betterment in other services sectors [7]. Thus, developing and formulating an efficient public transport system have become one of the primary objectives for planners and policy makers in many metropolitan cities across countries [8].

Many studies have investigated several correlation and impact of accessibility of public transport to the life satisfaction and environment that could cause a certain impact on quality of life and public health [4]. Improvement in the sustainability of public transport, public health, economic conditions of residents and environments can be achieved by reducing the use of private transport and shifting to the mass transport system and environmentally friendly transport such as cycling and walking [9].

The relation between job opportunities and accessibility for public transport has become an interesting topic to be investigated in many studies. One of the purposes of enhancing urban public transport systems is to improve commuting and also to facilitate individual performance on the employment market [4]. According to [10], a positive correlation between labor force attachment and transportation accessibility might not be caused by the public transport role, but is a result of spatial urban factors. Enhancing job accessibility might increase earnings and individual employment rates by various mechanisms [4].

Furthermore, according to [11], the correlation between employment and transport accessibility has mostly become an area of dispute in formulating transport infrastructure and geographic conditions. It seems that the job locations and the workforce's residential locations could be overcome by providing a sound transit system. Labors might not consider various relevant job opportunities due to long commuting time [12]. In this sense, the characteristics of a sound public transportation system can become one of productive strategy to challenge unemployment [13].

The relation between employment and access of transit system has been revealed by [13] which employed geographical information system to investigate the various labors characteristics within different transport systems. This study found that the transport accessibility has become one of the key factors in determining employment participation. Further, by evaluating the correlation between labor participation levels and transport access and employing the two-stage least squares regression model, [13] proved that a stronger relationship between labor participation and public transit accessibilities. Further, a study of [11] justified the previous study of [13]. In [11] was investigated the available network of public transport system influence on the employment rate variation at a local level and a statistically significant relationship between the shorter commuting time and higher employment levels was found.
In a recent study, [14] were analyzed the factors affecting women's decisions in choosing the transport mode in order to determine individual travel requirements that are affected by socio economic condition, life stages and gender. Their study employed 6000 household's data and investigated mobility behavior data provided by Zilina self-governing region from 2013 to 2016. Authors found that the relation of daily travel mode, characteristics of activity participation, and socio-demographics of male and female commuters were more gender sensitive.

\subsection{Influence of commuters on labor market supply}

An individual decision on doing the commuting can be caused by wages creating the process in the labor market that differs between areas. The amount of wages received by commuters is assumed to be the basis for them to choose transportation modes [15]. In this study, Jakarta's commuters that fill the labor market in 2014 have been attracted to the minimum wage policy that fixated on IDR 2,44 million. It was the highest minimum wage to be set compared to the other eight cities/regencies outside Jakarta. Other than Jakarta's minimum wages, transportation cost and housing price have accounted on household's decision making on whether they should be a commuter or not. Social demographic characteristics, such as education level, age, gender and race also influenced an individual decision on commuting [16].

Labor supply limitation due to migration will keep minimum wage high in the receiving labor market [17]. Meanwhile, commuters that are eager to increase their utilization to get the most satisfying pay and the job will travel back and forth in one day. This event will imply the unlimited labor availability in the city, additionally with a regional minimum wage policy set above other areas than Jakarta. Commuters flow will improve labor supply for the job in the commuters' receiving labor market. Hence, it will lower the cost of opening new job opportunities. Okun's Law has stated that decrease in labor demand on receiving labor market will affect in the rise of product and services demand, assuming that commuters utilize and spend their money in the district where they work, not where they originated from [16].

\subsection{Staying duration on current living area}

Sociodemographic characteristics affect an individual decision on doing the commuting. How long they have stayed in their current living area is one of the satisfaction indicators on migration process they perform, because it can describe the adaptation process of the immigrant to their environment [18]. Recent migration has limited staying duration up to five years compared to their current living area. For this reason, this study was aimed to find how the personal satisfaction to keep or stop being a commuter, regarding their duration of stay in their current living 
area. Staying duration will describe individual resilience on shortening their traveling distance to the workplace. The longer the staying duration, it will describe different individual decision on comfortability factors that cannot be offered by other areas.

\subsection{Commuting duration, distance and double- income household migration strategy}

Every individual has own resilience stability to perform commuting in a day for one hour [19]. If the commuting takes place more than an hour, it will affect individual decision making to stay as a commuter or to stop the act of commuting. Male commuter and female commuter have different resilience in commuting; where male are described as more resilient on long-distance commuting, this is not what happens with female commuters. Female commuters' resilience can be affected by the household conditions. Household where husband and wife are both working outside their original labor market will discuss whether they will stay as commuters or quit the job. A tendency to quit a job more likely happens to wives due to household conditions, the school-age child they have would make a female more likely to stop commuting and choose a job much closer to her home [20-21].

Additionally, the experience of having a long-distance commuting with a longer duration will affect an individual decision on staying or quitting as a commuter [22]. A study by [19] on measuring commuting resilience duration with survival analysis, while [22] divide subsamples of the research based on how long they have been commuting with multinomial analysis. In this study, the research team has used the survival analysis on the duration of staying in their current living area with individual decision to stay or stop being a commuter.

\section{$3 \quad$ Methodology}

This research uses Jabodetabek commuters in 2014 survey data that has been conducted by Statistics Indonesia. This survey has been conducted in five districts in Jakarta, namely South Jakarta, East Jakarta, Central Jakarta, West Jakarta, North Jakarta and eight surrounding cities and regencies, namely Bogor Regency, Bogor City, Bekasi Regency, Bekasi City, Depok, Tangerang Regency, Tangerang City and South Tangerang City. This research used 1,712 households whose household members perform commuting to Jakarta in one day back and forth to fulfill Jakarta's labor market. The total commuter individuals, who headed to Jakarta, were 3,522. To analyze the commuting resilience of the individual, 2,485 units sample, who has been living in their current living area up to 10 years, were gathered. Ten years of living decided as the limitation because many cases of quitting as a commuter happened in this period, although it is still an indifferent duration for commuters to stay or quit.
Survival analysis, in particular, the survivor function and hazard ratio will measure the commuters' resiliency. This research uses parametric survival regression with log logistic distribution. Survivor function $\mathrm{S}(\mathrm{t})$ is a function that stated individual chances to stay longer in their current living area and become a commuter to Jakarta up until the certain point of time, which can be defined as:

$S(t)=P(T \geq t)$.

The random variable $\mathrm{T}$ defined staying duration in the current living area and keep being a commuter. The probability density function $f(t)$ is:

$f(t)=-\frac{d S(t)}{d t}$,

proof:

$s(t)=\int_{t}^{\infty} f(x) d x$,

$\int_{-\infty}^{t} f(x) d x+\int_{t}^{\infty} f(x) d x=1$

$\int_{-\infty}^{t} f(x) d x=1-S(t)$

$\frac{d\left[\int_{-\infty}^{t} f(x) d x\right]}{d t}=\frac{d[1-S(t)]}{d t}$,

$f(t)=-\frac{d S(t)}{d t}$

On the other hand, the Hazard function is used to define the probability of someone to keep staying in their current living area and stop being a commuter in time $t$ subject to the provision of someone quitting as a commuter up until the time they are willing to quit. This study used 5.9 years as the limitation based on survival time mean. Given is the function:

$h(t)=\lim _{\delta t \rightarrow 0} \frac{P(t \leq T<t+\delta t \mid T \geq t)}{\delta t}$.

\subsection{Relation between Survivor function and Hazard function}

$$
\begin{aligned}
& P(t \leq T<t+\delta t \mid T \geq t)=\frac{P(t \leq T<t+\delta t)}{P(T \geq t)} \\
& =\frac{F(t+\delta t)-F(t)}{S(t)}, \\
& h(t)=\lim _{\delta t \rightarrow 0}\left\{\frac{P(t \leq T<t+\delta t \mid T \geq t)}{\delta t}\right\} \cdot \frac{1}{S(t)}, \\
& h(t)=\frac{f(t)}{S(t)} \\
& \text { because }(t)=-\frac{d S(t)}{d t}, \\
& \text { therefore } h(t)=-\frac{d}{d t}\{\log S(t)\},
\end{aligned}
$$


$\log \log S(t)=\int h(t) d t=H(t)$

$\log S(t) \exp (-H(t))$

The parametric method, applied in this study, is using analysis method with log logistic distribution assumption, after distribution test conducted with Matlab software. Thus, Survivor function and log-logistic distribution used in this study are defined as:

$$
\begin{aligned}
& S(t)=1-F(t)=1-\frac{e^{\theta} t^{k}}{1+e^{\theta} t^{k}}= \\
& =\frac{1+e^{\theta} t^{k}-e^{\theta} t^{k}}{1+e^{\theta} t^{k}}=\frac{1}{1+e^{\theta} t^{k}} .
\end{aligned}
$$

Meanwhile, Hazard function with log-logistic distribution will be:

$$
h(t)=\frac{f(t)}{S(t)}=\frac{k e^{\theta} t^{k-1}}{\left(1+e^{\theta} t^{k}\right)^{2}} \frac{1+e^{\theta} t^{k}}{1}=.
$$

The Accelerated Failure Time (AFT) log-logistic model was used to analyze the survival probability.

\subsection{Accelerated Failure Time (AFT) log-logistic model}

This model describes when the commuter stops happening faster than the survival time (accelerated failure time).

\subsection{Hazard function with the AFT model}

$$
\begin{aligned}
& h_{i}(t)=e^{\eta_{i}} h_{0}\left(e^{-\eta_{i}} t\right), \\
& h_{0}(t)=\text { Initial Hazard Function, } \\
& h_{i}(t)=\text { Initial Hazard Function on }-i, \\
& \eta_{i}=\beta_{1} x_{1 i}+\beta_{2} x_{2 i}+\cdots+\beta_{p} x_{p i},
\end{aligned}
$$

where $\mathrm{i}=1,2, \ldots, \mathrm{n}$.

\subsection{Survivor function with AFT model}

$$
\begin{aligned}
S_{i}(t) & =\frac{f i(t)}{h i(t)}, \\
S_{i}(t) & =\text { Initial Survivor function on }-i, \\
h_{i}(t) & =\text { Hazard function on }-i .
\end{aligned}
$$

How long commuter will stay in his current living area and keep being a commuter is estimated by $\left(\theta+k \eta_{i}, k\right)$ parameter.

\subsection{The log-linear format from Accelerated Failure Time log-logistic model}

Log linear is a group of a variable in surviving time $T_{i}$ :

$\log T_{i}=\mu+\alpha_{i} x_{1 i}+\cdots+\alpha_{p} x_{p i}+\sigma \varepsilon_{i}$.

Using the Survivor function definition, thus:

$$
\begin{aligned}
& S(t)=P(T \geq t)=P\left(\log T_{i} \geq \log t\right)= \\
& P\left(\varepsilon_{i} \geq \frac{\log t-\mu-\cdots-\sigma_{\rho} x_{\rho i}}{\sigma}\right) .
\end{aligned}
$$

Assuming that $\varepsilon$ distributes logistics, the density of opportunity function probability and Survivor function from $\varepsilon$ are:

$$
\begin{aligned}
f(\varepsilon) & =\frac{e^{\varepsilon}}{\left(1+e^{\varepsilon}\right)^{2}}, \\
S(\varepsilon) & =\frac{1}{1+e^{\varepsilon}} .
\end{aligned}
$$

Therefore, the Survivor function from $T_{i}$ is:

$S_{i}(t)=\left[1+\exp \left\{\frac{\log t-\mu-\cdots-\sigma_{\rho} x_{\rho i}}{}\right\}\right]^{-1}$.

The Survivor function, with i-individual distributes the log-logistic with $\left(\theta+k \eta_{i}, k\right)$ parameter estimation, where $\eta_{i}$ is:

$\eta_{i}=\beta_{1} x_{1 i}+\beta_{2} x_{2 i}+\cdots+\beta_{p} x_{p i}$.

The Survivor function given from $\mathrm{T}$ is:

$S_{i}(t)=\frac{1}{1+e^{\theta+k \eta_{i}} t^{k}}$.

Compared to T Survivor function that:

$\theta=-\frac{\mu}{\sigma}$

$k=\frac{1}{\sigma}$.

The Hazard ratio from the Proportional Odds Loglogistic model is:

$\frac{h_{i}(t)}{h_{0}(t)}=\left[1+\left(e^{\eta_{i}}-1\right) S_{0}(t)\right]^{-1}$.

\section{Results and discussion}

When forming its labor market, Jakarta as Indonesia's capital city cannot separate the local labor (stayers' labor) and labor who are mobile (movers' labor) with daily duration (commuting labor) or more than one-day duration (circular labor) in six months period. The increasing percentage of Jakarta, Banten and West Java's commuter labors indicated a spatial interaction to fulfill the labor market for each area. The Spatial interaction happened 
Table 1 Data descriptions

\begin{tabular}{|c|c|}
\hline & Log Logistic Survival \\
\hline \multirow[t]{2}{*}{ Variable } & 1 = Quit \\
\hline & $0=$ Stay \\
\hline Total Sample & $\mathrm{n}=2485$ \\
\hline \multicolumn{2}{|l|}{ Gender } \\
\hline Male & 1 \\
\hline Female & 2 \\
\hline \multicolumn{2}{|l|}{ Age } \\
\hline \multicolumn{2}{|l|}{ Education } \\
\hline Up to Elementary/Islamic Elementary or equivalent & 1 \\
\hline Junior High School/Islamic Junior High School or equivalent & 2 \\
\hline Senior High School/Islamic Senior High School or equivalent & 2 \\
\hline Diploma I/II/III & 4 \\
\hline Diploma IV/Bachelor/Master/Doctoral & 5 \\
\hline \multicolumn{2}{|l|}{ Homeownership status } \\
\hline Self-owned & 1 \\
\hline Rent/Contract & 2 \\
\hline Other & 3 \\
\hline \multicolumn{2}{|l|}{ Feeling stress when headed to/from receiving labor market } \\
\hline Yes & 1 \\
\hline No & 2 \\
\hline \multicolumn{2}{|l|}{ Commuting Duration } \\
\hline \multicolumn{2}{|l|}{ Mileage } \\
\hline \multicolumn{2}{|l|}{ Average income from the primary job } \\
\hline \multicolumn{2}{|l|}{ Double-income household } \\
\hline Yes & 1 \\
\hline No & 2 \\
\hline
\end{tabular}

in the form of labor mobilization that moves across their city or district border. This interaction implies the increase of income per capita on receiving labor market and an increase in welfare on the labor's origin area, especially for a household with commuter labor. This phenomenon can describe two sides of commuter labor as an input on production factor in the receiving labor market to produce output and as a resident of the area of origin with better income level compared to when they do not move. In [15] is explained that the commuter labor is most likely to work outside their current living area than in their origin area, assuming reservation wage for every labor is treated as equal.

This study has analyzed how the commuter labor's characteristics from the surrounding area of Jakarta, such as Banten district and West Java, are fulfilling Jakarta's labor market, based on Jabodetabek commuter survey in 2014 by Statistics Indonesia. Jakarta, as a megapolitan, has grown through the suburbanization process that happens in the surrounding area of Jakarta. This phenomenon, described by [23], happened where suburbanization takes place with spatial distribution pattern that spread more widely, along with the growth of metropolitan cities. Table 1 below describes the characteristics of respondents in this study.

Labor mobility that happens with a daily duration from the surrounding of Jakarta is an implication caused by suburbanization around Jakarta. $12.44 \%$ of labors from Depok fulfilled Jakarta's labor market and became the most significant percentage compared to the other 13 districts/ cities/regencies that directly bordered with Jakarta. 32.45\% of the commuter labor from 13 districts/cities/regencies around Jakarta, headed to South Jakarta and Central Jakarta every day. That describes how Jakarta's biggest economy happened in the Central and South Jakarta, supported by commuter labors from 13 districts/cities/ regencies. The Central and South Jakarta are the biggest Jakarta's most significant GDP contributors, with $24.34 \%$ contribution come from Central Jakarta and 22.35\% from South Jakarta. Moreover, commuter labors that headed to Jakarta fulfill governance and public service sector (21.78\%), trade sector (19.85\%), insurance and finance (12.21\%) and 
Table 2 Data analysis

\begin{tabular}{|c|c|c|c|c|}
\hline \multirow{3}{*}{ Variable } & \multirow{2}{*}{\multicolumn{2}{|c|}{$\begin{array}{l}\text { Total Samples } \\
\quad(\mathrm{n}=2485) \\
\text { Willing to Quit }\end{array}$}} & \multirow{3}{*}{$\begin{array}{l}\text { Full Model } \\
\text { Coefficient }\end{array}$} & \multirow{3}{*}{$\begin{array}{r}\text { Fitted Model } \\
\text { Coefficient }\end{array}$} \\
\hline & & & & \\
\hline & Yes & No & & \\
\hline Samples & 173 & 2312 & & \\
\hline \multicolumn{5}{|l|}{ Gender } \\
\hline Male & 126 & 1619 & & \\
\hline Female & 47 & 693 & $\begin{array}{c}0.0185968 \\
(0.1262742)\end{array}$ & \\
\hline Age & 173 & 2312 & $\begin{array}{l}0.0139384 * * \\
(0.0065005)\end{array}$ & $\begin{array}{r}0.0161032 * * \\
(0.0063751)\end{array}$ \\
\hline \multicolumn{5}{|l|}{ Education Level } \\
\hline Elementary/Islamic Elementary or equivalent & 14 & 100 & & \\
\hline $\begin{array}{l}\text { Junior High School/Islamic Junior High School or } \\
\text { equivalent }\end{array}$ & 11 & 169 & $\begin{array}{l}0.6434834 * * \\
(0.2849675)\end{array}$ & $\begin{array}{c}0.6277425 * * \\
(0.2879138)\end{array}$ \\
\hline $\begin{array}{l}\text { Senior High School/Islamic Senior High School or } \\
\text { equivalent }\end{array}$ & 94 & 1122 & $\begin{array}{c}0.5567855 * * * \\
(0.2094445)\end{array}$ & $\begin{array}{c}0.5765493 \text { *** } \\
(0.2113748)\end{array}$ \\
\hline Diploma I/II/III & 11 & 214 & $\begin{array}{c}0.8876308 \text { **** } \\
(0.2759957)\end{array}$ & $\begin{array}{c}0.9076511 * * * \\
(0.2778538)\end{array}$ \\
\hline Diploma IV/Bachelor/Master/Doctoral & 43 & 707 & $\begin{array}{c}0.7377673 * * \\
(0.2291076) \\
\end{array}$ & $\begin{array}{r}0.7590284 * * * \\
(0.2267885)\end{array}$ \\
\hline \multicolumn{5}{|l|}{ Home ownership status } \\
\hline Self-owned & 123 & 1723 & & \\
\hline Rent/Contract & 32 & 380 & $\begin{array}{l}-0.1110324 \\
(0.1402029)\end{array}$ & \\
\hline Other & 18 & 208 & $\begin{array}{l}-0.1814356 \\
(0.1768024)\end{array}$ & \\
\hline \multicolumn{5}{|l|}{$\begin{array}{l}\text { Feeling stress when heading toward/ } \\
\text { from the activity area }\end{array}$} \\
\hline Yes & 111 & 1058 & & \\
\hline No & 62 & 1254 & $\begin{array}{c}0.3410174 \text { *** } \\
(0.1089175)\end{array}$ & $\begin{array}{c}0.3290216 * * * \\
(0.1091749)\end{array}$ \\
\hline Commuting Duration & 173 & 2312 & $\begin{array}{l}-0.003817 * * \\
(0.0016782)\end{array}$ & $\begin{array}{l}-0.0023322 * \\
(0.0013896)\end{array}$ \\
\hline Mileage (Distance) & 173 & 2312 & $\begin{array}{l}0.0067719 \\
(0.004922)\end{array}$ & \\
\hline The average income per month from the primary job & & & $\begin{array}{l}-1.58 \mathrm{e}-08 \\
(7.72 \mathrm{e}-09)\end{array}$ & \\
\hline \multicolumn{5}{|l|}{ Double-Income Household } \\
\hline Yes & 65 & 833 & $\begin{array}{c}-0.1936276 * \\
(0.1121168)\end{array}$ & $\begin{array}{c}-0.1963347 * \\
(0.1101553\end{array}$ \\
\hline No & 108 & 1479 & & \\
\hline Constants & & & $\begin{array}{l}1.953655^{* * * *} \\
(0.3370987)\end{array}$ & $\begin{array}{c}1.886609 \text { **** } \\
(0.3215616)\end{array}$ \\
\hline 1/ln_gamma & & & $\begin{array}{c}-0.8366013 \text { *** } \\
(0.0916982)\end{array}$ & $\begin{array}{c}-0.826973 \text { *** } \\
(0.0918275)\end{array}$ \\
\hline gamma & & & $\begin{array}{c}0.4331803 \\
(0.0397219) \\
\end{array}$ & $\begin{array}{c}0.4373712 \\
(0.0401627) \\
\end{array}$ \\
\hline
\end{tabular}

$* \mathrm{p}<0.10, * * \mathrm{p}<0.05, * * * \mathrm{p}<0.01$ 
Table 3 Surviving probability and Hazard ratio on quitting as a commuter

\begin{tabular}{|c|c|c|c|c|c|}
\hline \multirow{3}{*}{ Variable } & \multirow{2}{*}{\multicolumn{2}{|c|}{$\begin{array}{c}\text { Survivor Function } \\
\text { Stay as a Commuter }\end{array}$}} & \multirow{2}{*}{\multicolumn{2}{|c|}{$\begin{array}{c}\text { Hazard Function } \\
\text { Quit as a Commuter }\end{array}$}} & \multirow{3}{*}{$\begin{array}{c}\begin{array}{c}\text { Hazard } \\
\text { Ratio }\end{array} \\
\text { i }\end{array}$} \\
\hline & & & & & \\
\hline & 0 & $\mathrm{i}$ & 0 & $\mathrm{i}$ & \\
\hline Global & 0.466 & & -0.10 & & \\
\hline Age & & 0.471 & & -0.108 & 0.992 \\
\hline \multicolumn{6}{|l|}{ Education Level } \\
\hline \multicolumn{6}{|l|}{$\begin{array}{l}\text { Elementary/Islamic Elementary } \\
\text { or equivalent }\end{array}$} \\
\hline Junior High School/Islamic Junior High School or equivalent & & 0.799 & & -0.041 & 0.376 \\
\hline $\begin{array}{l}\text { Senior High School/Islamic Senior High School or } \\
\text { equivalent }\end{array}$ & & 0.876 & & -0.025 & 0.232 \\
\hline Diploma I/II/III & & 0.986 & & -0.003 & 0.026 \\
\hline Diploma IV/Bachelor/Master/Doctoral & & 0.989 & & -0.002 & 0.022 \\
\hline \multicolumn{6}{|l|}{ Feeling stress when heading toward/from the activity area } \\
\hline \multicolumn{6}{|l|}{ Yes } \\
\hline No & & 0.659 & & -0.070 & 0.639 \\
\hline Commuting Duration & & 0.466 & & -0.110 & 1.002 \\
\hline \multicolumn{6}{|l|}{ Double-Income Household } \\
\hline Yes & & 0.488 & & -0.105 & 0.960 \\
\hline No & & & & & \\
\hline
\end{tabular}

manufacturing industry (11.73\%). These four sectors are the most significant contributor to Jakarta's gross domestic, local product and become the main characteristic of a big city such as Jakarta. In 2014, the trading sector contributed $16.64 \%$ to Jakarta's GDP, followed by governance and public service sector (15.18\%), manufacturing (12.94\%) and financial services (10.21\%).

The technology development, marked by better transportation system, which connects Jakarta and its surroundings, has affected the commuter labors to mobilize and head toward to Jakarta without any significant time constraint. According to [19], a stable individual will travel to his receiving labor market in 60 minutes duration. Additionally, $40.60 \%$ commuter labor who headed to Jakarta, are more likely to travel in 31-60 minutes duration and $16.7 \%$ travel for $11-20 \mathrm{~km}$ from their home to their workplace. Travel duration can be an indicator to describe the commuter labor supply from the surrounding area that fills the Jakarta's labor market.

Jakarta, where most of the economic activities happened, has attracted labors from outside of Jakarta to take a role in the labor market. Most of Jakarta's commuters come from the surrounding area of Jakarta and become a recent immigrant, not a resident. Experience on becoming an immigrant, where they have long experience to live in their current area that differs from where they lived five years ago, is an indicator of immigration satisfaction [18]. $8.92 \%$ of commuters have lived in their current area for five years or different home compared to five years ago. While $57.04 \%$ have experienced living in the area other than their current districts/cities/regencies, $19.39 \%$ of the commuters live in their current place following where their husband/ wife/parents/kids live. $11.19 \%$ of them said it is because of housing and followed by working reason $8.21 \%$. Therefore, it contributed to individual decision to stay in their current home or choose to seek a home near their workplace and decide to quit as a commuter.

Commuting duration and previous experience as an immigrant are the reason why individual decided to maximize their utilization to stay in their current area. $30.72 \%$ commuters explained that they decided to commute because of the security and convenience in their current living area, while $13.49 \%$ commuters are willing to sacrifice their two hours to go to work for their current living area. On the other hand, Jakarta's labor market has become the reason for $34.64 \%$ commuters to get the job that matches their skills and competence. Table 2 below describes the results of the data analysis.

$6.39 \%$ stated that they want to make a better living through higher income, compared to their current living area. That can be an indicator what happens in the labor mobility where the opportunity of getting higher income in receiving labor market is more significant than in their current living area [24].

Rational individual choice is more likely to lean to the decision to avoid long commuting time [22, 25]. Thus, every individual will maximize their utilization when facing two choices between stay or quit as a commuter. This research used willingness to quit as a commuter for the next one-year approach to limit the event on analyzing commuter resilience on fulfilling Jakarta's labor market. According to Jabodetabek commuter survey in 2014, 70.56\% 
commuter decided to stay in their current living area for less than or up to 10 years. Therefore, this study takes that sub-population to see their commuting resilience to their decision on quitting as commuter labor. Table 3 below indicates results of the commuter decision.

Nearly one-third of the commuter labors fulfilled Jakarta's labor market and contributed to Jakarta's economy. Commuter labors resilience can be drawn by examining their commuting duration. According to [19], 60 minutes that every labor takes every day to commute is a description of labor's duration stability. It describes how the individual resilience on commuting in one day. Therefore, if commuting is done repeatedly more than one hour a day, it will deflate the individual's utilization. Thus, according to [25], the individual will tend to find a home closer to their workplace.

Staying duration in the current living area can describe the adaptation process every recent migrant is going through, where they had a different living area with what they have today. Staying duration is also closely related to immigrant's psychological wellness [26]. When the adaptation process is not going well and the burden of commuting duration is more significant than before, commuters may be affected by a psychological disorder, which in this study can be described with stress and plan to quit on being a commuter in the next year. Meanwhile, a household with double income where husband or wife work, and both are commuters will be more likely to face a tendency to decide which one will quit as a commuter. In majority of cases, women tend to quit as a commuter [22].

A study by [22] described that the duration of being a commuter could be affected by education level and gender. While age does not describe someone's willingness to quit as a commuter or have a shorter duration on commuting, it is still an aspect that needs to be considered regarding the ability to perform commuting. Related to a commuting distance where housing location is formed in the surrounding area of Jakarta, home ownership status becomes an essential consideration for someone on deciding to have a home closer to their workplace and quit being a commuter.

This research used survival analysis in seeing commuter resilience on commuting with current living area approach as a stimulus to migrate, shortening their commuting duration from home to workplace based on their commuting adaptability to their environment.

Based on Table 2, it describes that gender, distance, income and home ownership do not affect the respondent's decision whether to stay or quit as commuters. The fittest model exhibits that age, education level, the psychological condition, commuting duration and availability of spouse who is also a commuter can affect individual's decision to stay or quit as a commuter.

This research used parametric survival regression where gamma value was defined as a shape from data distribution that describes the hazard value. The Survival model on the duration of staying in Jakarta's commuter has shown a declining hazard value. Thus, it can describe how individual choose to stay as a commuter.

In the end, Jakarta's government can apply a policy that will comfort commuters and help them to stay as a commuter.

In Table 3 is shown that commuter probability of staying a commuter is more significant than the hazard of quitting as a commuter. Based on the education level, Jakarta has offered much more job opportunity for those who earn education higher than senior high school level compared to the local area. Therefore, the higher the education level, the more commuters will stay as a commuter rather than quit. In order to keep their labor working in their origin area, commuter's area of origin must develop economic activities that will expand jobs opportunity for labor with higher education level qualification. Additionally, a regional minimum wage that Jakarta has established already matches the commuter's utility. It can be seen through commuter's probability to stay rather than to quit as a commuter.

Based on age, the hazard ratio was found to be higher than the opportunity to stay as a commuter. The older is the commuter, the more likely they want to work in their origin area and fulfill their local area labor market, rather than being a commuter in the future. This is also the case of a double-income household where the probability of one of the household members is more likely to quit as a commuter is more significant due to the internal decision in the household, regarding the family condition and where the school-aged kid is in the household or not. Thus, the female commuter is more likely to fill the local's labor market rather than being a commuter [22]. For the commuting duration, the longer the commuting takes time, the higher the chance of someone to quit as a commuter. However, this is not the case where commuter does not feel any stress on commuting. The more commuter resistance to stress, the probability of quitting or staying is almost the same.

Jakarta offers significant job opportunities with tight competition. It has attracted commuter labor to participate in Jakarta's labor market. Productive age with higher level education commuter is more likely to contribute to Jakarta's labor market. On the other hand, to maintain the large numbers of commuters to Jakarta's economy, the public transportation system must be able to make commuters feel at ease on their commuting time so that long commuting time will not be a constraint for a commuter to keep on commuting.

\section{Conclusions}

With the growing economy activities in Jakarta, the surrounding area of Jakarta will eventually get spillover from this event. One of the aspects that is most likely to be affected is the labor market. With the development towards a better transportation system, housing price and opportunities available in the megapolitan city, it surely will attract more labors from outside of Jakarta to participate in Jakarta's labor market. However, several factors are playing 
a role in commuter labor decision making, whether they want to stay or quit as a commuter.

The policy implications for improving the labor supply provision and some contested policy options are suggested such as the provision of affordable housing in Jakarta, the creation of jobs within the Jakarta's surrounding cities and improvement of the commuting enjoyment.

Labors with a higher educational level are those who are willing to stay as a commuter in order to pursue their most wanted and most suitable job for their qualification. Jakarta has offered much more opportunities compared to its surrounding areas such as Depok, Bogor, Tangerang and Banten. However, as labor grow older, they are more likely to stay in their area of origin and plan to quit as a commuter, especially if the commuting time is longer than one hour and trigger stress on the labor. This is also the case of women commuter, especially if they already have a spouse and a school-aged kid, where they are more likely to quit as a commuter due to household decision making.

Jakarta surroundings already has its advantage of the lower house pricing compared to Jakarta. Thus, the provision of affordable housing in Jakarta will help retaining labor supply. However, the lower housing prices and rents would be a trigger to labors to be commuters. Furthermore, most people are still reluctant to work in the surrounding area of Jakarta due to the small number of job opportunities given by the local labor market. If Jakarta's surrounding area wants to retain their residents to work in their area, jobs opening, especially for labor with a higher level of education, must be attractive enough to the employee candidates. It can be started by giving better incentives and more job opportunities that match their qualifications and interests.

If Jakarta wants to retain their numerous commuter labors, it must improve the transportation system. Not only the inner-city transportation that must be developed but the intercity transportation, as well. Therefore, it will make commuters more likely to head to Jakarta because there will be no more significant constraint to head to work, especially the time constraint. Tariff reduction on public transportation can also play a role to retain and attract more labor from the surrounding area. In addition, the enjoyment during the traveling time must be taken into consideration. A seamless experience for commuters, when changing their transportation modes would be very much welcomed. Additionally, entertainment during the commuting is also useful to reduce boredom such as access to free internet.

\section{References}

[1] TEMPO, 2019. BI: Jakarta Contributes to 17 Percent of Indonesia`s Economy - Tempo [online]. [Viewed 2019-11-05]. 2018. Available at: https://en.tempo.co/read/922840/bi-jakarta-contributes-to-17-percent-of-indonesias-economy

[2] BUDIARI, I. 1.38 million commute into Jakarta daily. The Jakarta Post [online]. 2015 [accessed 2019-11-05]. ISSN 0215-3432. Available from: https://www.thejakartapost.com/news/2015/02/17/138-million-commute-jakartadaily.html

[3] BUHAUG, H., URDAL, H. An urbanization bomb? Population growth and social disorder in cities. Global Environmental Change[online] . 2013, 23(1), p. 1-10. ISSN 0959-3780. Available from: https://doi.org/10.1016/j.gloenvcha.2012.10.016

[4] SAIF, A., ZEFREH, M., TOROK, A. Public transport accessibility: a literature review. Periodica Polytechnica Transportation Engineering [online]. 2018, 47(1), p. 36-43. ISSN 0303-7800. eISSN 1587-3811. Available from: https://doi.org/10.3311/PPtr.12072

[5] KONECNY, V., BEREZNY, R., PETRO, F., TRNOVCOVA, M. Research on demand for bus transport and transport habits of high school students in Zilina region. LOGI - Scientific Journal on Transport and Logistics [online]. 2017, 8(2), p. 47-58. ISSN 2336-3037. Available from: https://doi.org/10.1515/logi-2017-0016

[6] SAMEK LODOVICI, M., TORCHIO, N. Social inclusion in EU public transport. Directorate-general for internal policies [online]. European Union, 2015. Available from: http://www.europarl.europa.eu/studies

[7] ABREHA, D. A. (2007). Analysing Public Transport Performance Using Efficiency Measures and Spatial Analysis: The Case of Addis Ababa, Ethiopia. Thesis Report, International Institute for Geo-information Science and Earth Observation, Enschede, the Netherlands.

[8] SAGHAPOUR, T., MORIDPOUR, S., THOMPSON, R. G. (2016). Public transport accessibility in metropolitan areas: A new approach incorporating population density. Journal of Transport Geography. 54, pp. 273-285. https://doi.org/10.1016/j.jtrangeo.2016.06.019

[9] ELIAS, W., SHIFTAN, Y. The influence of individual's risk perception and attitudes on travel behavior. Transportation Research Part A: Policy and Practice [online]. 2012, 46(8), p. 1241-1251. ISSN 0965-8564, eISSN 1879-2375. Available from: https://doi.org/10.1016/j.tra.2012.05.013

[10] KORSU, E., WENGLENSKI, S. Job accessibility, residential segregation and risk of long-term unemployment in the Paris region. Urban Studies [online]. 2010, 47(11), p. 2279-2324. ISSN 0042-0980, eISSN 1360-063X. Available from: https://doi.org/10.1177/0042098009357962

[11] JOHNSON, D., ERCOLANI, M., MACKIE, P. Econometric analysis of the link between public transport accessibility and employment. Transport Policy [online]. 2017, 60, p. 1-9. ISSN 0967-070X, eISSN 1879-310X. Available from: https://doi.org/10.1016/j.tranpol.2017.08.001 
[12] PHILLIPS, D. C. Long commutes or neighborhood perceptions: Why do employers avoid applicants from highpoverty neighborhoods? [online]. Available from: http://poverty.ucdavis.edu/sites/main/files/file-attachments/ phillips_proposal_web.pdf

[13] SANCHEZ, T. W. The connection between public transit and employment. Journal of the American Planning Association [online]. 1999, 65(3), p. 284-296. ISSN 0194-4363, eISSN 1939-0130. Available from: https://doi.org/10.1080/01944369908976058

[14] POURHASHEM, G., BUZNA, L., KOVACIKOVA, T., HUDAK, M. Exploring women travel behaviour in the region of Zilina from large scale mobility survey. In: Reliability and Statistics in Transportation and Communication RelStat 2018 : proceedings. KABASHKIN I., YATSKIV (JACKIVA) I., PRENTKOVSKIS O. (eds) [online]. Lecture Notes in Networks and Systems. Vol 68. Cham: Springer. ISBN 978-3-030-12449-6, eISBN 978-3-030-12450-2. Available from: https://doi.org/10.1007/978-3-030-12450-2_10

[15] ROUWENDAL, J. Search theory and commuting behavior. Growth and Change [online]. 2004, 35(3), p. 391-418. eISSN 1468-2257. Available from: https://doi.org/10.1111/j.1468-2257.2004.00254.x

[16] RUSSO, G., TEDESCHI, F., REGGIANI, A., NIJKAMP, P. Commuter effects on local labor markets: A German modelling study. Urban Studies [online]. 2014, 51(3), p. 493-508. ISSN 0042-0980, eISSN 1360-063X. Available from: https://doi.org/10.1177/0042098013498281

[17] SAMUELSON, P. A. Economics. New York: McGraw-Hill, 1964.

[18] NETO, F., FONSECA, A. M. The satisfaction with migration life scale. International Journal of Intercultural Relations [online]. 2016, 54, p. 47-54. ISSN 0147-1767. Available from: https://doi.org/10.1016/j.ijintrel.2016.07.004

[19] JOLY, I. Stability or regularity of the daily travel time in Lyon? Application of a duration model. International Journal of Transport Economics. 2006, 33(3), p. 369-400. ISSN 0303-5247, eISSN 1724-2185.

[20] GREEN, A. E. A question of compromise? Case study evidence on the location and mobility strategies of dual career households. Regional Studies [online]. 1996, 31(7), p. 641- 657. ISSN 0034-3404, eISSN 1360-0591. Available from: https://doi.org/10.1080/00343409750130731

[21] SANDOW, E. Commuting behavior in sparsely populated areas: evidence from northern Sweden. Journal of Transport Geography [online]. 2010, 16(1), p. 14-27. ISSN 0966-6923, eISSN 1873-1236. Available from: https://doi.org/10.1016/j.jtrangeo.2007.04.004

[22] SANDOW, E., WESTIN, K. The persevering commuter - duration of long-distance commuting. Transportation Research Part A: Policy and Practice [online]. 2010, 44(6), p. 433-445. ISSN 0965-8564, eISSN 1879-2375. Available from: https://doi.org/10.1016/j.tra.2010.03.017

[23] HENDERSON, V. Medium size cities. Regional Science and Urban Economics [online]. 1997, 27(6), p. 583-612. ISSN 0166-0462. Available from: https://doi.org/10.1016/S0166-0462(96)02169-2

[24] BORJAS, G. J. Labor economics. New York: McGraw-Hill Education, 2013. ISBN 978-0073523200.

[25] ZELINSKY, W. The hypothesis of the mobility transition. Geographical Review [online]. 1971, 61(2), p. 219-249. ISSN 0016-7428, eISSN 1931-0846. Available from: https://doi.org/10.2307/213996

[26] WARD, C., BOCHNER, S., FURNHAM, A. The Psychology of culture shock. 1. ed. East Sussex: Routledge, 2001. ISBN 0-415-16234-3. 